\title{
Association between tooth agenesis and cancer: a systematic review
}

\section{Abstract}

Melany Clarissa Gámez MEDINA ${ }^{1 *}$ iD

Renata Travassos da Rosa Moreira BASTOS $^{1 *}$ iD

Paulo MECENAS ${ }^{\text {* }}$ João de Jesus Viana PINHEIRO² David NORMANDO²
Submitted: November 23, 2020 Modification: February 3, 2021 Accepted: April 6, 2021

Corresponding address: David Normando Rua Augusto Corrêa, 01 - 66075-110 -
Belém - Pará - Brazil.
Phone: +55 (91) 99144-6316 Rua Augusto Corrêa, 01 - 66075-110 -
Belém - Pará - Brazil.
Phone: +55 (91) 99144-6316 e-mail: davidnormando@hotmail.com
The congenital absence of multiple teeth may share the same genetic background of the development of some types of cancer. Objective: This systematic review aimed to investigate the possible association between dental agenesis and cancer, and the perspective of agenesis as an early predictor for cancer risk. Methodology: The electronic databases PubMed, Scopus, Web of Science, Cochrane Library, LILACS, and OpenGrey were searched and the risk of bias was evaluated using the Newcastle-Ottawa tool. The GRADE tool was used to evaluate the certainty of the evidence. Results: Six studies met the eligibility criteria. A positive co-occurrence between ovarian cancer and hypodontia was found in two articles. Three studies evaluated the association between dental agenesis and colorectal cancer and only one showed common genes for these conditions. One paper found individuals with hypodontia had a higher risk of family history of cancer. Five studies had a fair quality and one a good quality. The certainty of evidence was classified as very low. Conclusion: Notwithstanding the limited scientific evidence, there may be a possible association between dental agenesis and cancer due to genes involved in both conditions. Agenesis of multiple teeth could be an early indicator of cancer risk. Nevertheless, studies with a better level of evidence are needed to confirm this possible association.

Keyword: Tooth agenesis. Neoplasm. Cancer. Anodontia.
'Universidade Federal do Pará, Programa de Pós-Graduação em Odontologia, Belém, Pará, Brasil. ${ }^{2}$ Universidade Federal do Pará, Faculdade de Odontologia, Belém, Pará, Brasil.

${ }^{*}$ These authors contributed equally to this work. 


\section{Introduction}

Tooth agenesis is a common dental anomaly in humans, with prevalence around $6.4 \%$ and variation according to sex, race, and ethnicity. ${ }^{1}$ Hypodontia is the condition characterized by the absence of less than six permanent teeth, oligodontia more than six missing teeth, and anodontia in case of missing all permanent teeth. ${ }^{2,3}$ Except for the third molars, lower second premolars and upper lateral incisors are the permanent teeth most affected. ${ }^{1,4}$

Some environmental factors could interfere with odontogenesis, which includes trauma, infection, smoking, surgery, and others. ${ }^{5-8}$ Tooth agenesis is also related with genetic syndromes including ectodermal dysplasia and Klinefelter syndrome. ${ }^{9}$ Therefore, this condition may also be classified as syndromic or nonsyndromic. ${ }^{4,10}$ In both situations, the genetic seems to be the main etiological component. ${ }^{11}$

Mutations and single nucleotide polymorphism (SNP) in some genes, such as axis inhibition protein 2 (AXIN2), ${ }^{12}$ muscle segment homeobox 1 (MSX1), ${ }^{13}$ paired box gene 9 (PAX9), ${ }^{14}$ and wingless type MMTV integration site family, member $10 A$ (WNT10A $)^{15}$ have been related with dental agenesis and interestingly, mutations in these genes may be connected with many types of cancers. ${ }^{16}$

The link between dental agenesis and cancer may be elucidated by three factors: (1) there are genes involved in odontogenesis that are present in tumor tissues or cells; ${ }^{17,18}$ (2) nucleotide changes on some genes are related with both odontogenesis and cancer ${ }^{19}$ and the mutations appear to disturb odontogenesis early in life and later contribute to the carcinogenesis; (3) according to epigenetics, the aberrant methylation of these genes was observed in neoplasm samples. ${ }^{20}$

There is still divergence in the literature about this relationship. Some studies showed an association between dental agenesis and cancer, ${ }^{21,22}$ while others do not. ${ }^{23,24}$ There is a great clinical relevance in this issue since the absence of multiple teeth may be an indicator of cancer. Therefore, this systematic review aims to verify the connection between dental agenesis and cancer, considering a single tooth agenesis or even oligodontia, and the possibility that agenesis is an early indicator for cancer risk.

\section{Methodology}

This review was registered at PROSPERO database (CRD42019129901) and performed according to PRISMA guidelines. ${ }^{25}$ The process was performed separately by two reviewers. A third reviewer was consulted when there was no agreement between the two reviewers.

\section{Eligibility criteria}

The following eligibility criteria were adopted in this systematic review in accordance to the PECOS format: Population (P): humans; Exposure (E): any type of tooth agenesis; Comparison (C): absence of tooth agenesis; Outcome (O): any type of cancer or family history of cancer; Study design (S): case-control, cross-sectional, or cohort. Studies which evaluated syndromic patients, cases of tooth extraction, patients with cleft lip and palate and third molar agenesis were excluded, as well as opinion articles, animal studies, laboratory studies, case reports, case-series, and literature reviews.

\section{Information sources}

The databases PubMed, Scopus, Web of Science, Cochrane Library, OpenGrey, and LILACS were searched between the $15^{\text {th }}$ and $21^{\text {st }}$ of January and the alerts were followed up until the $5^{\text {th }}$ of September. A manual search was carried out in the reference list of the included studies for eventual relevant article missed during the searches. No restriction on language or publication date was used.

\section{Search strategy and study selection}

The search strategy was created using words associated with the PECOS strategy and these words were combined using Boolean operators. The search strategy for each database is presented in Figure 1. All relevant references have been imported into the software Endnote ( $x 9$ version, Clarivate Analytics, Philadelphia, PA, USA). After duplicate removal, titles, and abstracts were evaluated considering the selection criteria. The included studies were accessed by full text read for further assessment and data extraction.

\section{Data extraction}

The following information was extracted from the selected articles: author, year, country, study design, type of cancer, total cases/controls, incidence of tooth 


\begin{tabular}{|c|c|c|}
\hline Database & \begin{tabular}{|c|} 
Search strategy \\
\end{tabular} & Results \\
\hline Pubmed & 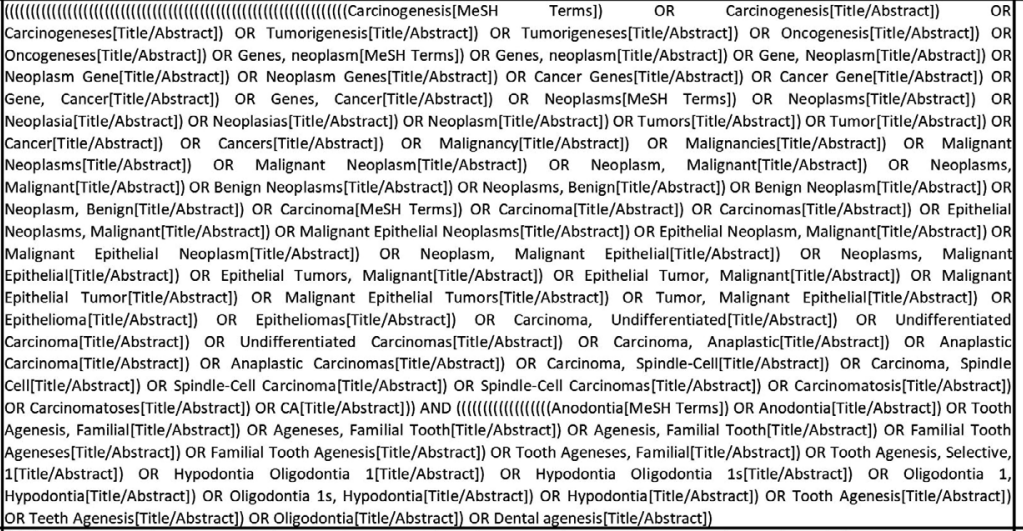 & 273 \\
\hline Scopus & 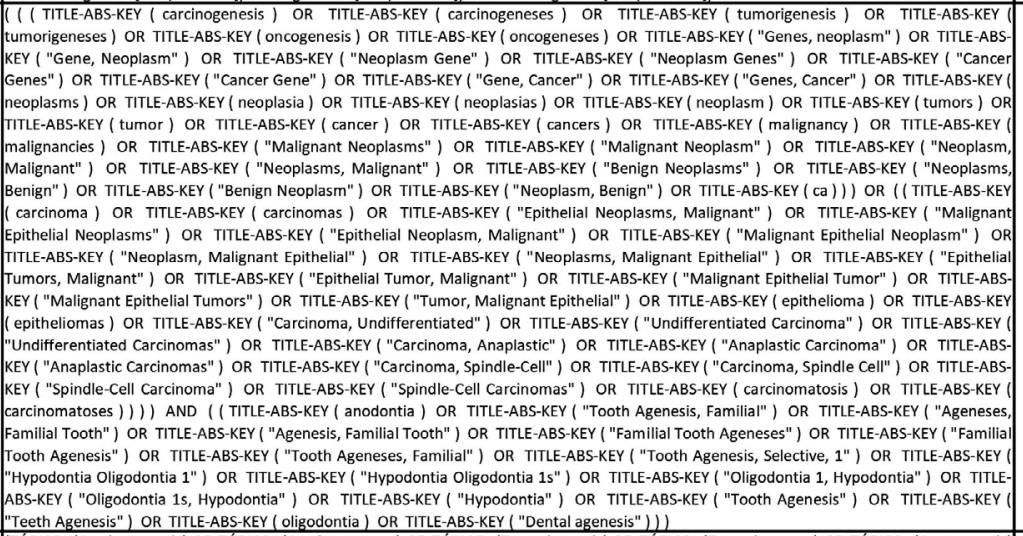 & 367 \\
\hline $\begin{array}{l}\text { Web of } \\
\text { Science }\end{array}$ & 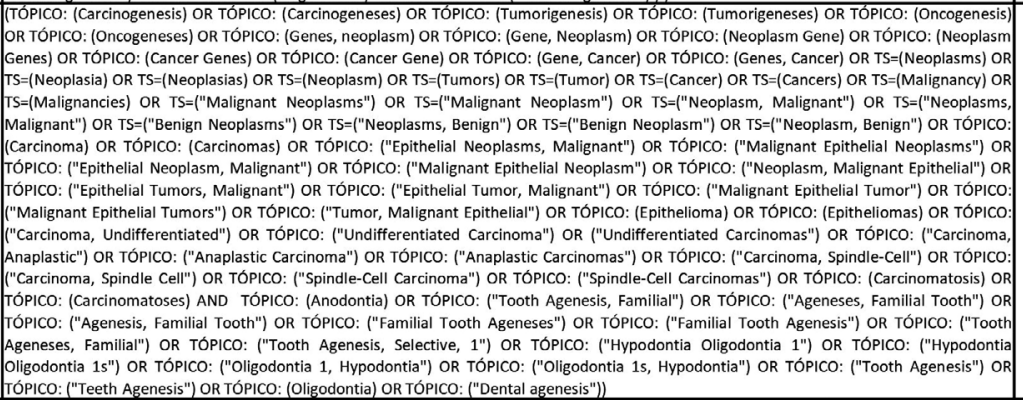 & 146 \\
\hline Cochrane & 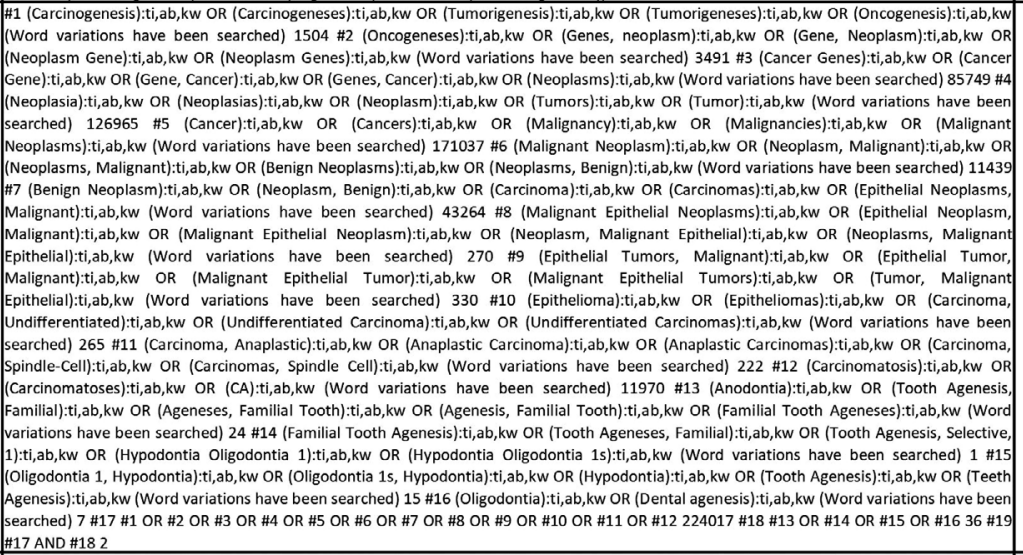 & 2 \\
\hline LILACS & 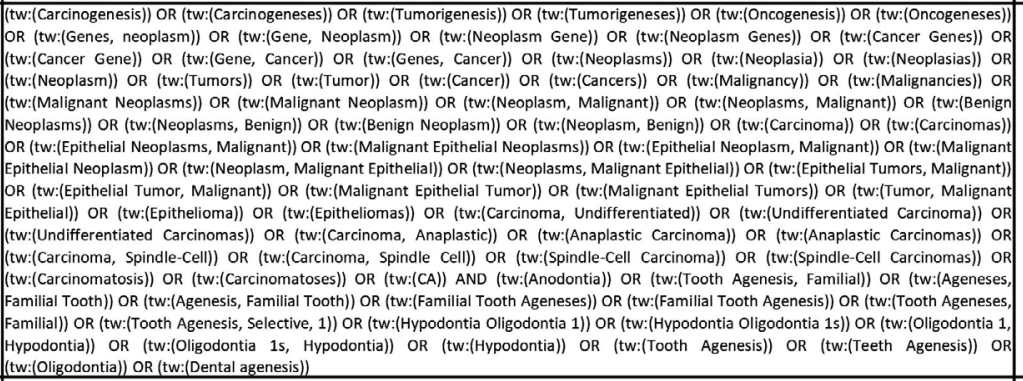 & 39 \\
\hline Open Grey & "tooth agenesis" and cancer & \\
\hline
\end{tabular}

Figure 1- Search strategy 
agenesis, mean age, most frequent missing teeth, family history of cancer, genetic analysis, evaluation method, statistical analysis, and main results.

\section{Risk of bias in individual studies}

The Newcastle-Ottawa toll was used to assess the risk of bias. ${ }^{26}$ All studies were evaluated by eight items, grouped into three domains: selection of the study groups, comparability of groups and exposure or outcome assessment for case-control, and cohort studies, respectively. One star was awarded for each quality item, with a maximum of nine stars for the highest quality studies. If the score was eight or more stars the study was classified as "good," between five and seven as "fair," equal or less than four as "poor."

\section{Summary measurements}

The difference in prevalence rates of tooth agenesis between control and case groups was determined by using the $p$-value $<0.05$. The association was calculated through the Odds Ratio with a 95 percent confidence interval.

\section{Certainty of evidence}

The certainty of evidence was assessed using the Grading of Recommendations, Assessment, Development, and Evaluation Pro software (GRADE) (GRADEpro, gradepro.org.). ${ }^{27}$ The GRADE analyzes five domains to classify the certainty of evidence: type of study, risk of bias, consistency, directness, and precision of the articles. The certainty of evidence was rated as high, moderate, low, or very low. The outcomes assessed were: "association between tooth agenesis and ovarian cancer," "association between tooth agenesis and colorectal cancer" and "association between tooth agenesis and family history of cancer."

\section{Results}

\section{Study selection}

The electronic screening found 827 articles: 273 from PubMed, 367 from Scopus, 146 from Web of Science, two from Cochrane Library, 39 from LILACS, and zero from OpenGrey. After removing duplicates studies, 543 articles were identified. After the authors performed title and abstract screening, 20 articles were assessed by full text. Among them, 14 were excluded for the reasons shown in Figure 2. Finally, six studies were selected for qualitative analysis of risk of bias (Figure 3).

\section{Characteristics of included articles}

The characteristics of the six included articles are presented in Table 1 . They were observational and case-control studies. ${ }^{21,22,24,28-30}$ Two articles investigated the association between tooth agenesis and ovarian cancer, ${ }^{21,22}$ whereas three assessed the interrelation of colorectal cancer with tooth agenesis. ${ }^{24,29,30}$ One article investigated the co-occurrence of dental agenesis and family history of cancer. ${ }^{28}$ One of the studies that investigated the relationship between agenesis and colorectal cancer also identified family history of cancer; nonetheless, it was not statistically tested or discussed in the manuscript. ${ }^{30}$ Therefore, we decided to perform an Odds Ratio to assess this association.

A considerable difference was found in relation to the sample sizes. The sample sizes of the control groups ranged from $44^{24}$ to $4188,{ }^{29}$ while the sample sizes for the case groups ranged from $6^{24}$ to $236 .{ }^{29}$ The mean age was only reported by one article. ${ }^{30}$ The diagnosis of dental agenesis was made through clinical, $21,22,24,28,30$ radiographic examination, ${ }^{21,22,24,28,30}$ and a selfreport questionnaire. ${ }^{24,29}$ The tooth with the highest percentage of congenital absence were upper lateral

\begin{tabular}{c|c}
\hline Reference & Reason for exclusion \\
\hline Abadie et al. (2013) & Letter to editor \\
\hline Beard et al. (2019) & Case report \\
\hline Bonds et al. (2014) & Absence of control group \\
\hline Cardoso et al. (2018) & Review \\
\hline Fekonja et al. (2015) & Case report \\
\hline Gawron-Jakubek et al. (2019) & Review \\
\hline Hattab et al. (2017) & Review \\
\hline Hlouskova et al. (2017) & Absence of control group \\
\hline lavazzo et al. (2016) & Opinion article \\
\hline Lammi et al. (2004) & Problems in eligibility criteria \\
\hline Longtin et al. (2004) & Review \\
\hline Otero et al. (2019) & Review \\
\hline Ritwik et al. (2018) &
\end{tabular}

Figure 2- List of excluded studies with reasons for exclusion 
incisor, ${ }^{21,22,24,28}$ second upper premolars, ${ }^{21,22,24}$ second lower premolars, ${ }^{22,24}$ and lower central incisors. ${ }^{22}$ The diagnosis of cancer was not detailed in the studies, although they report patients were diagnosed and recruited from cancer treatment centers. ${ }^{21,22,24,29}$ The family history of cancer was evaluated in the included studies through questionnaires ${ }^{28}$ or self-reports. ${ }^{30}$ Two studies ${ }^{28,30}$ evaluated the relation through genes analysis, which were: AXIN2, FGF3, FGF10, FGFR2, ${ }^{28}$ ATF1, DUSP10, CASC8. ${ }^{30}$

\section{Results of individual studies}

Two studies detected an association between the congenital absence of tooth and ovarian cancer. ${ }^{21,22}$ Other two articles did not report an association between colorectal cancer and dental agenesis, ${ }^{24,29}$ whereas one showed common genes for both conditions: ATF1, DUSP10, and CASC8. ${ }^{30}$ One study found subjects with dental agenesis had a major chance of family history of cancer and associations with AXIN2, FGF3, FGF10, and FGFR2 genes. $^{28}$

\section{Synthesis of results}

It was not possible to perform a meta-analysis because of the low number of articles investigating the analyzed outcomes. However, an odds ratio was performed for each study individually and for each type of cancer or family history of cancer. It was revealed a statistically significant association between dental agenesis and ovarian cancer, with a chance of a patient with ovarian cancer being diagnosed with tooth agenesis 6.43 higher. No statistically significant association was observed between agenesis and colorectal cancer, which is corroborated by the $p$-value and the $95 \%$ confidence interval. Finally, a statistically significant association was also noticed between family history of cancer and dental agenesis and the results shows a chance 2.71 times greater of the co-occurrence of these two conditions (Table 2 ).

\section{Risk of bias assessment}

The quality of five studies was classified as fair, ${ }^{22,24,28-30}$ and one study as good (Table 3 )..$^{21}$ Limitations were found in the main domains evaluated.
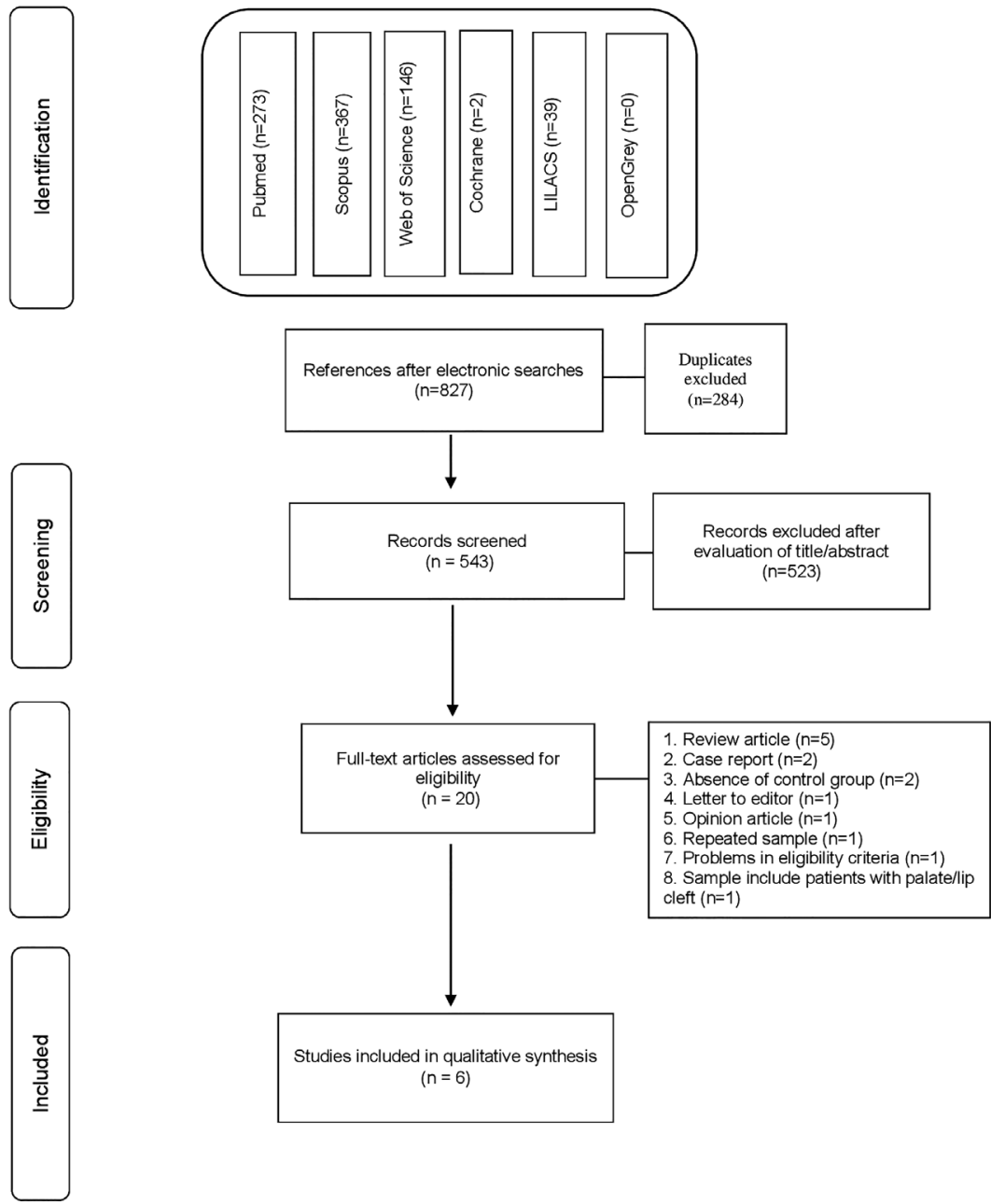

Figure 3- Flowchart with number of records at each stage of the review according to PRISMA statement 
The domain "selection of study groups" exhibited deficiencies such as inadequate case definition; ${ }^{29}$ poor representativeness of the cases ${ }^{21-24.28-30}$, and lack of information on the selection of controls. ${ }^{22-24,29}$ The deficiency in the representativeness of the cases was characterized by no description of the recruitment location of control subjects. The domain "comparability of groups" presented limitations in the item "no control of important confounding factors (e.g. gender, age)."24
Two articles showed inaccurate outcome assessments due to evaluation by self-reporting. ${ }^{28,30}$

\section{Level of evidence}

The GRADE evaluation found a very low certainty of evidence for the three outcomes assessed (Figure 4 ). This can be associated with the study design and risk of bias of included articles.

Table 1-Summary of the data from the studies included in this review

\begin{tabular}{|c|c|c|c|c|c|c|c|c|c|c|}
\hline \multirow{2}{*}{$\begin{array}{l}\text { Authors, } \\
\text { year, location } \\
\text { and type of } \\
\text { study }\end{array}$} & \multirow[t]{2}{*}{$\begin{array}{l}\text { Type of } \\
\text { cancer }\end{array}$} & \multicolumn{2}{|c|}{ Sample } & \multirow[t]{2}{*}{$\begin{array}{l}\text { Mean Age } \\
\text { (years) }\end{array}$} & \multirow{2}{*}{$\begin{array}{l}\text { Most } \\
\text { frequent } \\
\text { missing } \\
\text { tooth }\end{array}$} & \multirow{2}{*}{$\begin{array}{l}\text { Family history } \\
\text { of cancer } \\
\text { control/ case } \\
(\%)\end{array}$} & \multirow[t]{2}{*}{ Genes } & \multirow[t]{2}{*}{ Evaluation method } & \multirow[t]{2}{*}{$\begin{array}{l}\text { Statistical } \\
\text { analysis }\end{array}$} & \multirow[t]{2}{*}{ Main results } \\
\hline & & $\begin{array}{l}\text { Without } \\
\text { tooth } \\
\text { agenesis } \\
\text { (with cancer } \\
\text { or family } \\
\text { history) }\end{array}$ & $\begin{array}{l}\text { With tooth } \\
\text { agenesis } \\
\text { (with } \\
\text { cancer } \\
\text { or family } \\
\text { history) }\end{array}$ & & & & & & & \\
\hline $\begin{array}{l}\text { Chalothorn et } \\
\text { al., }{ }^{21}(2008), \\
\text { USA, Case- } \\
\text { control }\end{array}$ & $\begin{array}{l}\text { Epithelial } \\
\text { Ovarian } \\
\text { cancer } \\
\text { (EOC) }\end{array}$ & $127(30)$ & $23(20)$ & - & U2, U5 & - & - & - & $\begin{array}{l}\text { Fisher } \\
\text { exact, OR }\end{array}$ & $\begin{array}{c}\text { Possible association } \\
\text { between EOC and } \\
\text { agenesis. The data } \\
\text { also showed that the } \\
\text { crude OR was } 8.1 \text { ( } 95 \\
\text { percent } \mathrm{Cl}, 2.1-30.9 \text { ), } \\
\text { which implied that } \\
\text { women with EOC are } \\
8.1 \text { times more likely to } \\
\text { have hypodontia than } \\
\text { are women without } \\
\text { EOC. }\end{array}$ \\
\hline $\begin{array}{c}\text { Fekonja et } \\
\text { al., }{ }^{22}(2014), \\
\text { Slovenia, } \\
\text { Case-Control }\end{array}$ & $\begin{array}{l}\text { Epithelial } \\
\text { Ovarian } \\
\text { cancer } \\
\text { (EOC) }\end{array}$ & $209(97)$ & $31(23)$ & - & $\begin{array}{l}\text { U5, U2, } \\
\text { L5, L1 }\end{array}$ & - & - & $\begin{array}{l}\text { Clinical and X-rays } \\
\text { evaluations }\end{array}$ & $\begin{array}{c}\text { t-test, } X^{2} \text {, } \\
\text { Fisher } \\
\text { exact, OR }\end{array}$ & $\begin{array}{c}\text { The difference between } \\
\text { the two groups was } \\
\text { statistically significant } \\
(\mathrm{p}=0.004) \text {; the crude } \\
\text { OR was } 3.30(95 \% \\
\mathrm{Cl}, 0.12-7.01) . \\
\text { Women with ovarian } \\
\text { cancer were } 2.87 \\
\text { times }(19.2 \%-6.7 \%) \\
\text { more likely to have } \\
\text { hypodontia than } \\
\text { healthy women. }\end{array}$ \\
\hline $\begin{array}{l}\text { Paranjyothi et } \\
\text { al. }{ }^{24}(2018), \\
\text { India, Case- } \\
\text { control }\end{array}$ & $\begin{array}{l}\text { Colorectal } \\
\text { cancer } \\
\text { (CRC) }\end{array}$ & $44(21)$ & $6(4)$ & - & L5, U2, U5 & - & - & $\begin{array}{l}\text { Self-reported } \\
\text { questionnaire,clinical } \\
\text { and X-rays } \\
\text { evaluations }\end{array}$ & $X^{2}$ & $\begin{array}{c}\text { Sixteen percent of } \\
\text { cancer patients and } 8 \% \\
\text { of individuals without } \\
\text { cancer reported having } \\
\text { tooth agenesis, no } \\
\text { statistical difference ( } p= \\
0.384) \text {. }\end{array}$ \\
\hline $\begin{array}{l}\text { Lindor et } \\
\text { al., }{ }^{29}(2014), \\
\text { Canada, } \\
\text { Case-control }\end{array}$ & $\begin{array}{l}\text { Colorectal } \\
\text { cancer } \\
\text { (CRC) }\end{array}$ & $4188(1558)$ & $236(78)$ & - & - & - & - & $\begin{array}{l}\text { Self-reported } \\
\text { questionnaire }\end{array}$ & $\begin{array}{l}\mathrm{X}^{2} \text {, Fisher } \\
\text { exact test }\end{array}$ & $\begin{array}{l}4.8 \% \text { of cases and } \\
5.7 \% \text { of controls } \\
\text { reported having at least } \\
\text { one missing tooth, no } \\
\text { statistical evidence of } \\
\text { difference }(p=0.20) \text {. }\end{array}$ \\
\hline $\begin{array}{l}\text { Williams et } \\
\text { al.., }{ }^{30}(2018), \\
\text { USA, Case- } \\
\text { control }\end{array}$ & $\begin{array}{l}\text { Colorectal } \\
\text { cancer } \\
\text { (CRC) } \\
\text { and family } \\
\text { history of } \\
\text { any type } \\
\text { of cancer }\end{array}$ & 347 (39) & $93(28)$ & - & - & $11,2 \% / 30,1 \%$ & $\begin{array}{c}\text { ATF1, } \\
\text { DUSP10, } \\
\text { CASC8 }\end{array}$ & $\begin{array}{l}\text { Clinical and } \\
\text { radiographic } \\
\text { examinations and } \\
\text { associated gene } \\
\text { variants }\end{array}$ & - & $\begin{array}{c}\text { Genome-wide } \\
\text { significant associations } \\
\text { were found between } \\
\text { TA and ATF1 }(P=4.36 \\
\times 10-10) \text { and DUSP10 } \\
(P=1.25 \times 10-9) \text {, and } \\
\text { positive association } \\
\text { found with CASC8 }(P= \\
8.2 \times 10-5) .\end{array}$ \\
\hline $\begin{array}{l}\text { Küchler et } \\
\text { al.. }{ }^{28}(2013), \\
\text { USA/Brazil, } \\
\text { Case-control }\end{array}$ & $\begin{array}{l}\text { Family } \\
\text { history of } \\
\text { any type } \\
\text { of cancer }\end{array}$ & $328(102)$ & $82(45)$ & $\begin{array}{l}\text { Case: } 18.15 \pm \\
10.2 \text { Control: } \\
20.33 \pm 14.9\end{array}$ & $\begin{array}{l}\text { U4, L4, U5 } \\
\text { L5, U2, } \\
\text { L1, L2 }\end{array}$ & $\begin{array}{l}31,1 \% / \\
54,90 \%\end{array}$ & $\begin{array}{l}\text { AXIN2, } \\
\text { FGF3, } \\
\text { FGF10, } \\
\text { FGFR2 }\end{array}$ & $\begin{array}{c}\text { Structured } \\
\text { questionnaire and } \\
\text { clinical and X-rays } \\
\text { evaluations }\end{array}$ & $\begin{array}{l}\text { Student's } \\
\text { t test, OR, } \\
X^{2}, \text { Fisher's } \\
\text { exact tests }\end{array}$ & $\begin{array}{l}\text { Individuals with tooth } \\
\text { agenesis had an } \\
\text { increased prevalence } \\
\text { of having a family } \\
\text { history of cancer } \\
\text { OR }=2.7 ; 95 \% \text { C.I., } \\
\text { 1.6-4.4). A significant } \\
\text { association between } \\
\text { AXIN2, FGF3, FGF10, } \\
\text { and FGFR2 and tooth } \\
\text { agenesis was found. }\end{array}$ \\
\hline
\end{tabular}

U2 - Upper lateral incisor; L1 - Lower central incisor; U4/5 - Upper premolars; L4/5 - Lower premolar, CRC: colorectal cancer; AXIN2: Axis inhibition protein 2. 
Table 2- Odds ratio of the included studies

\begin{tabular}{|c|c|c|c|c|c|c|c|c|c|}
\hline $\begin{array}{l}\text { Cancer } \\
\text { type or } \\
\text { family } \\
\text { history }\end{array}$ & Study & Group & $\begin{array}{l}\text { With } \\
\text { cancer } \\
\text { or family } \\
\text { history }\end{array}$ & $\begin{array}{l}\text { Without } \\
\text { cancer } \\
\text { or family } \\
\text { history }\end{array}$ & Total & $\begin{array}{l}\text { OR/95CI } \\
\text { (Study) }\end{array}$ & $\begin{array}{l}\text { p-value } \\
\text { (study) }\end{array}$ & $\begin{array}{c}\text { OR/95CI } \\
\text { (each cancer } \\
\text { type or family } \\
\text { history) }\end{array}$ & $\begin{array}{c}\text { p-value } \\
\text { (each } \\
\text { cancer type } \\
\text { or family } \\
\text { history) }\end{array}$ \\
\hline \multirow{4}{*}{$\begin{array}{l}\text { Ovarian } \\
\text { cancer }\end{array}$} & \multirow{2}{*}{$\begin{array}{l}\text { Chalothorn et } \\
\text { al. }{ }^{21}(2008)\end{array}$} & $\begin{array}{c}\text { With } \\
\text { agenesis }\end{array}$ & 20 & 3 & 23 & \multirow{2}{*}{$\begin{array}{c}\text { OR: } 21.56 / 5.99- \\
77.58\end{array}$} & \multirow{2}{*}{$<0.0001$} & \multirow{4}{*}{$\begin{array}{l}\text { OR: } 6.43 / \\
3.20-12.93\end{array}$} & \multirow{4}{*}{$<0.0001$} \\
\hline & & $\begin{array}{l}\text { Without } \\
\text { agenesis }\end{array}$ & 30 & 97 & 127 & & & & \\
\hline & \multirow{2}{*}{$\begin{array}{l}\text { Fekonja et } \\
\text { al., }{ }^{22}(2014)\end{array}$} & $\begin{array}{c}\text { With } \\
\text { agenesis }\end{array}$ & 23 & 8 & 31 & \multirow{2}{*}{$\begin{array}{c}\text { OR: } 3.32 / 1.42- \\
7.76\end{array}$} & \multirow{2}{*}{0.0070} & & \\
\hline & & $\begin{array}{l}\text { Without } \\
\text { agenesis }\end{array}$ & 97 & 112 & 209 & & & & \\
\hline \multirow{4}{*}{$\begin{array}{l}\text { Colorectal } \\
\text { cancer }\end{array}$} & \multirow{2}{*}{$\begin{array}{l}\text { Paranjyothi et } \\
\text { al., }{ }^{24}(2018)\end{array}$} & $\begin{array}{c}\text { With } \\
\text { agenesis }\end{array}$ & 4 & 2 & 6 & \multirow{2}{*}{$\begin{array}{c}\text { OR: } 2.19 / 0.36- \\
13.22\end{array}$} & \multirow{2}{*}{0.6634} & \multirow{4}{*}{$\begin{array}{l}\text { OR: } 0.86 / \\
0.66-1.13\end{array}$} & \multirow{4}{*}{0.3151} \\
\hline & & $\begin{array}{l}\text { Without } \\
\text { agenesis }\end{array}$ & 21 & 23 & 44 & & & & \\
\hline & \multirow{2}{*}{$\begin{array}{l}\text { Lindor et al. }{ }^{29} \\
(2014)\end{array}$} & $\begin{array}{c}\text { With } \\
\text { agenesis }\end{array}$ & 78 & 158 & 236 & \multirow{2}{*}{$\begin{array}{c}\text { OR: } 0.83 / 0.63- \\
1.10\end{array}$} & \multirow{2}{*}{0.2240} & & \\
\hline & & $\begin{array}{l}\text { Without } \\
\text { agenesis }\end{array}$ & 1558 & 2630 & 4188 & & & & \\
\hline \multirow{4}{*}{$\begin{array}{l}\text { Family } \\
\text { history of } \\
\text { cancer }\end{array}$} & \multirow{2}{*}{$\begin{array}{l}\text { Williams et } \\
\text { al., }{ }^{30}(2018)\end{array}$} & $\begin{array}{c}\text { With } \\
\text { agenesis }\end{array}$ & 28 & 65 & 93 & \multirow{2}{*}{$\begin{array}{c}\text { OR: } 3.40 / 1.95- \\
5.92\end{array}$} & \multirow{2}{*}{$<0.0001$} & \multirow{4}{*}{$\begin{array}{l}\text { OR: } 2.71 / \\
1.90-3.86\end{array}$} & \multirow{4}{*}{$<0.0001$} \\
\hline & & $\begin{array}{l}\text { Without } \\
\text { agenesis }\end{array}$ & 39 & 308 & 347 & & & & \\
\hline & \multirow{2}{*}{$\begin{array}{l}\text { Küchler et } \\
\text { al., }{ }^{28}(2013)\end{array}$} & $\begin{array}{c}\text { With } \\
\text { agenesis }\end{array}$ & 45 & 37 & 82 & \multirow{2}{*}{$\begin{array}{c}\text { OR: } 2.69 / 1.64- \\
4.4155\end{array}$} & \multirow{2}{*}{0.0001} & & \\
\hline & & $\begin{array}{l}\text { Without } \\
\text { agenesis }\end{array}$ & 102 & 226 & 338 & & & & \\
\hline
\end{tabular}

Table 3- Risk of Bias of the studies, according to the Newcastle-Ottawa Scale

\begin{tabular}{ccccc}
\hline Study & $\begin{array}{c}\text { Selection } \\
\text { (maximum 4 stars) }\end{array}$ & $\begin{array}{c}\text { Comparability } \\
\text { (maximum 2 stars) }\end{array}$ & $\begin{array}{c}\text { Outcome or exposure } \\
\text { assessment } \\
\text { (maximum 3 stars) }\end{array}$ & Total score (Quality) \\
\hline Chalothorn et al., ${ }^{21}(2008)$ & 3 & 2 & 3 & 8 (Good) \\
\hline Fekonja et al., ${ }^{22}(2014)$ & 2 & 2 & 3 & 6 (Fair) \\
\hline Paranjyothi et al., ${ }^{24}(2018)$ & 2 & 1 & 3 & 6 (Fair) \\
\hline Lindor et al., ${ }^{29}(2014)$ & 1 & 2 & 3 & 7 (Fair) \\
\hline Küchler et al., ${ }^{28}(2013)$ & 3 & 2 & 2 & 7 (Fair) \\
\hline Williams et al., ${ }^{30}(2018)$ & 3 & 2 & 2 & \\
\hline
\end{tabular}

\section{Discussion}

Odontogenesis is an intricate process of reciprocal interaction with the involvement of a larger number of genes and the opportunity of mutations in many of these genes can disrupt this process and be associated with hypodontia. ${ }^{22,28}$ The genes that command teeth development also have important functions and molecular association with other organs and body systems. Therefore, a genetic alteration culminating in hypodontia can lead to abnormalities in other parts of the human body. ${ }^{21}$ Some selected articles in this systematic review point to a potential association between dental agenesis and neoplasm. ${ }^{19,21,28,31-33}$

One of the most related genes to dental agenesis is AXIN2. The protein expressed by this gene has an important function in craniofacial morphogenesis. ${ }^{16}$ Patients with SNP of the AXIN2 gene do not have permanent molars, premolars, lower incisors, and upper incisors. ${ }^{18}$ Interestingly, mutations in the AXIN2, MSX1, PAX9, and WNT10A genes may be associated with cancers. ${ }^{16}$ This condition refers to a phenomenon called pleiotropy, characterized by a single genetic locus that truly affects multiple apparently unrelated phenotypic traits. It is often identified as a single mutation that affects two or more wild-type traits in 


\begin{tabular}{|c|c|c|c|c|c|c|c|c|c|}
\hline \multicolumn{7}{|c|}{ Certainty assessment } & \multirow[b]{2}{*}{ Impact } & \multirow[b]{2}{*}{ Certainty } & \multirow[b]{2}{*}{ Importance } \\
\hline № of studies & Study design & Risk of bias & Inconsistency & Indirectness & Imprecision & $\begin{array}{c}\text { Other } \\
\text { considerations }\end{array}$ & & & \\
\hline \multicolumn{10}{|c|}{ Association between tooth agenesis and ovarian cancer } \\
\hline 2 & $\begin{array}{l}\text { observational } \\
\text { studies }\end{array}$ & serious $^{\text {a.b.c }}$ & serious $^{d}$ & not serious & not serious & none & $\begin{array}{l}\text { In two studies, 54 subjects with } \\
\text { dental agenesis and } 336 \text { without } \\
\text { were evaluated. One had a good risk } \\
\text { of bias and the other was classified } \\
\text { as a fair risk of bias. These studies } \\
\text { concluded that there is an } \\
\text { association between dental agenesis } \\
\text { and ovarian cancer. }\end{array}$ & $\begin{array}{c}\text { } \\
\text { VERY LOW } \\
\text { VEROW }\end{array}$ & CRITICAL \\
\hline \multicolumn{10}{|c|}{ Association between tooth agenesis and colorectal cancer } \\
\hline 3 & $\begin{array}{l}\text { observational } \\
\text { studies }\end{array}$ & serious $^{a, b, c}$ & not serious & not serious & not serious & none & $\begin{array}{l}\text { In three studies, } 335 \text { individuals with } \\
\text { tooth agenesis and } 4,579 \text { without } \\
\text { were evaluated. All articles } \\
\text { presented fair risk of bias. Two } \\
\text { studies do not conclude that are an } \\
\text { association between tooth agenesis } \\
\text { and colorectal cancer, while another } \\
\text { study that genes involved in } \\
\text { colorectal cancer may also be } \\
\text { involved in tooth development. }\end{array}$ & $\begin{array}{c}\text { MOOO } \\
\text { VERY LOW } \\
\text { VEW }\end{array}$ & CRITICAL \\
\hline \multicolumn{10}{|c|}{ Association between tooth agenesis and family history of cancer } \\
\hline 2 & $\begin{array}{l}\text { observational } \\
\text { studies }\end{array}$ & serious $^{\mathrm{a}, \mathrm{b}, \mathrm{c}}$ & not serious & not serious & not serious & none & $\begin{array}{l}\text { In two studies, } 328 \text { individuals with } \\
\text { tooth agenesis and } 82 \text { without were } \\
\text { evaluated. All articles presented fair } \\
\text { risk of bias. Association between } \\
\text { tooth agenesis and family history of } \\
\text { cancer was found in both studies. }\end{array}$ & $\begin{array}{l}\oplus O O O \\
\text { VERY LOW }\end{array}$ & CRITICAL \\
\hline
\end{tabular}

Explanations: a. Limitations in cases and controls selection.; b. Poor representativeness of the cases; $c$. Deficiencies in the groups comparability; $d$. Divergence in studies results.

Figure 4- Grade evidence profile table

human complex diseases that share the same genetic pathways. ${ }^{34,35}$

\section{Summary of evidence}

Six final articles were screened in this systematic review, and methodological characteristics were analyzed. In relation to the classification of the articles using the Newcastle-Ottawa tool, five studies were classified as fair quality, $22,24,28-30$ and one as good ${ }^{21}$ due, among other factors, to poor representativeness of the cases. The GRADE tool was used for the assessment of the certainty of evidence. A very low certainty of evidence was scored because of the study designs, and the result obtained in the assessment of risk was biased.

In two included studies, the authors verified the association between dental agenesis and ovarian cancer. ${ }^{21,22}$ Chalothorn, et al. ${ }^{21}$ (2008) used dental and medical records to assess family history of cancer and tooth agenesis. The dental examination was conducted to detect clinically hypodontia or any phenotype involved with this congenital dysfunction, like microdontia and agenesis. As a result, the authors found an increased prevalence of tooth agenesis in patients with epithelial ovarian cancer. In another study, conducted by Fekonja, Čretnik, and Takač22 (2014) women diagnosed with epithelial ovarian cancer were evaluated through clinical examination and panoramic radiography to confirm the diagnosis of hypodontia. The results showed a possible association between the two conditions. The OR confirmed a significant association between ovarian cancer and tooth agenesis. The result indicated the chance of a patient with ovarian cancer be diagnosed with a pattern of dental agenesis is 6.43 times greater (Table 2).

The findings of these two studies ${ }^{21,22}$ differ from other results in the literature that point to independent causation of these conditions. ${ }^{23}$ The authors analyzed the ovarian cancer sample in a cohort study and do not prove that the two conditions are independent from each other, but a genetic connection between them needs more epidemiological studies and molecular analysis to be confirmed. The absence of an adequate control group definition did not allow its inclusion in this systematic review. ${ }^{23}$

Regarding the association between dental agenesis and colorectal cancer, one ${ }^{29}$ of the three included $\operatorname{articles}^{24,29,30}$ used a questionnaire to self-report information on congenitally missing teeth. This was a limitation since a dental clinician did not examine the participants, and therefore justified the fair quality rating. The authors concluded the study did not provide scientific evidence strong enough to prove the predisposition of dental agenesis among colorectal cancer patients. The second study ${ }^{24}$ which verified this association agrees with the results obtained by Lindor, et al. ${ }^{29}$ (2014). The patients with colorectal cancer revealed an increased prevalence of dental agenesis when confronted to patients without history 
of this cancer, but it was not statistically significant. Our OR results, as well, demonstrated no statistically significant association between the two conditions, as demonstrated by the $\mathrm{p}$-value and $95 \%$ confidence interval (Table 2).

The major contrast from this study ${ }^{24}$ to the Lindor, et al.'s ${ }^{29}$ (2014) was the clinical and radiographic analysis of tooth agenesis, which was performed by the same dentist to avoid interexaminer bias, in the first, ${ }^{24}$ compared to a self-reported questionnaire of hypodontia in the second. ${ }^{29}$

In the third included article, ${ }^{30}$ the dental diagnosis was made by a dentist through clinical and radiographic exams. This study carried out a genetic analysis for which the authors selected 30 colorectal cancerpredisposing single nucleotide variants with genomewide significance. The authors concluded the genes related with colorectal cancer may also be involved in odontogenesis, and it provides extra perception into clarifying complex etiology and association between colorectal cancer and hypodontia. Furthermore, they found new genes and gene pathways continue with an unknown role in relation to tooth development.

Studies showed an increased presence, in patients with congenital missing teeth, of cancer in relatives ${ }^{29,30}$ and a genetic link would be manifested more strongly in first-degree relatives. ${ }^{36}$ To verify this relationship, Küchler, et al. ${ }^{28}$ (2013) studied the family history of cancer and its co-occurrence with tooth agenesis, corroborating the hypothesis that both conditions share a similar genetic background, with an increased overall cancer occurrence between relatives of people with tooth agenesis. Over a decade ago, Lammi, et al. ${ }^{19}$ (2004) first visualized a genetic alteration in the AXIN2 gene that causes both situations in a large multiplex family. The results obtained with OR showed a significant association between tooth agenesis and a family history of cancer, being the chance of a patient with family history of cancer being diagnosed with tooth agenesis 2.71 times higher (Table 2).

Dental agenesis is a failure in the odontogenesis process that occurs at the beginning of tooth morphogenesis. ${ }^{37}$ It is well known the etiology is related with genetic and environmental factors, ${ }^{38}$ and it may be part of a phenotypic expression of a syndrome or occur in isolation. ${ }^{37}$ The genes that are often associated with non-syndromic dental agenesis are AXIN2, MSX1, PAX9, EDA, and WNT10.39,40

It has been reported the association of AXIN2 gene with colorectal cancer. ${ }^{19,33,41}$ However, this relationship has not been demonstrated yet, ${ }^{42,43}$ which corroborates the results of this systematic review. In consequence, the polymorphism in AXIN2 gene may be considered a biological risk marker for predisposition and prognosis of colorectal cancer. ${ }^{41} \mathrm{~A}$ possible genetic relationship between dental agenesis and colorectal cancer has also been studied by Williams, et al. ${ }^{30}$ (2018) which reported the ATF1, DUSP10 and CASC8 genes may be related to colorectal cancer and to odontogenesis.

The hypothesis of tooth agenesis as a risk factor can be considered when evaluated the association with ovarian cancer, helping in its the early detection. In this case, however, it was not found an inherent gene that might be the causal factor responsible for the connection between the two conditions, as recently reported in the literature. ${ }^{44}$ The genes BRCA1 e BRCA2 are the strongest recognized genetic risk factors for epithelial ovarian cancer, ${ }^{45}$ although some studies show an association with the AXIN2 gene in several cancers, including the ovarian one. ${ }^{30,46}$ The epidemiology of the epithelial ovarian cancer requires attention, because it is considered the fifth most common cause of cancer in women and the fourth leading cause of cancer death, ${ }^{47,48}$ with a prognosis of approximately 18 months for women with an advanced stage, and $40-50 \%$ of overall survival for all ovarian cancer at ten years. ${ }^{49}$ It is important the attempt of early establish the co-occurrence between the epithelial ovarian cancer and the dental agenesis as a risk factor, mainly because of the aggressiveness of this type of cancer, that is considered malignantly fatal and silent, therefore to the difficult of diagnosis, ${ }^{21,50}$ as the major symptoms are not specific ${ }^{51}$ and as the lack of effective screening markers. ${ }^{46}$ Some hypothesis that would be useful in the identification of ovarian cancer are to check the family history of this cancer ${ }^{52}$ and to identify tooth agenesis as a risk marker. ${ }^{44}$

\section{Limitations}

Some aspects of this systematic review need further attention. Firstly, there were wide variations in the evaluation methods used to diagnose tooth agenesis in the studies. For future research, adequate and standardized methods of diagnoses and data collection are necessary. Secondly, small samples may not allow for statistically significant results. An issue related to the sample size was responsible for a fair quality in the study conducted by Paranjyothi, 
et al. ${ }^{24}$ (2018).

A possible genetic relationship between cancer and dental agenesis was suggested in the discussion, as genes involved in both conditions were reported. Nevertheless, the GRADE tool certainty of the evidence was classified as very low because of the observational study design and methodological flaws of the included articles. Thus, this subject needs to be studied more deeply, and a possible association should not be ruled out. More studies are needed, preferably prospective, to clarify the predictive value of tooth agenesis as an early indicator of cancer risk.

\section{Conclusions}

Considering the limited scientific evidence, it is possible there is an association between dental agenesis and cancer. Tooth agenesis could then be an early indicator for cancer. Therefore, it is important for dentists to carefully observe cases of multiple agenesis in their offices and to indicate a more rigorous medical follow-up. Nevertheless, studies with a better level of evidence are needed to confirm this association.

\section{Conflicts of interest}

There are no conflicts of Interest.

\section{Authors' contributions}

\section{Medina, Melany Clarissa Gomez:} Conceptualization (Equal); Data curation (Equal); Formal analysis (Equal); Investigation (Equal); Methodology (Equal); Writing-original draft (Equal).

Bastos, Renata Travassos da Rosa Moreira: Conceptualization (Equal); Data curation (Equal); Formal analysis (Equal); Investigation (Equal); Methodology (Equal); Project administration (Equal); Supervision (Equal); Visualization (Equal); Writingoriginal draft (Equal); Writing-review \& editing (Equal). Mecenas, Paulo: Data curation (Equal); Formal analysis (Equal); Investigation (Equal); Methodology (Equal); Validation (Equal); Visualization (Equal); Writing-original draft (Equal); Writing-review \& editing (Equal). Pinheiro, João de Jesus Viana: Supervision (Supporting); Writing-review \& editing (Equal). Normando, David: Conceptualization (Equal); Project administration (Equal); Supervision (Equal); Writingreview \& editing (Equal).

\section{References}

1- Khalaf K, Miskelly J, Voge E, Macfarlane TV. Prevalence of hypodontia and associated factors: a systematic review and meta-analysis. J Orthod. 2014;41(4):299-316. doi: 10.1179/1465313314Y.0000000116 2- Bock NC, Lenz S, Ruiz-Heiland G, Ruf S. Nonsyndromic oligodontia: Does the Tooth Agenesis Code (TAC) enable prediction of the causative mutation? J Orofac Orthop. 2017;78(2):112-20. doi: 10.1007/s00056016-0056-y.

3- Schalk-van der Weide Y, Steen WH, Bosman F. Distribution of missing teeth and tooth morphology in patients with oligodontia. ASDC J Dent Child.1992;59(2):133-40

4- Gkantidis N, Katib H, Oeschger E, Karamolegkou M, Topouzelis N, Kanavakis G. Patterns of non-syndromic permanent tooth agenesis in a large orthodontic population. Arch Oral Biol. 2017;79:42-7. doi: 10.1016/j.archoralbio.2017.02.020

5- Gawade PL, Hudson MM, Kaste SC, Neglia JP, Constine LS, Robinson $\mathrm{LL}$, et al. A systematic review of dental late effects in survivors of childhood cancer. Pediatr Blood Cancer. 2014;61(3):407-16. doi: $10.1002 /$ pbc. 24842

6- Seremidi K, Kloukos D, Polychronopoulou A, Kattamis A, Kavvadia $K$. Late effects of chemo and radiation treatment on dental structures of childhood cancer survivors: a systematic review and meta-analysis. Head Neck. 2019;41(9):3422-33. doi: 10.1002/hed. 25840

7- Al-Ani AH, Antoun JS, Thomson WM, Merriman TR, Farella M. Maternal smoking during pregnancy is associated with offspring hypodontia. J Dent Res. 2017;96(9):1014-9. doi: 10.1177/0022034517711156 8- Hölttä P, Alaluusua S, Saarinen-Pihkala UM, Peltola J, Hovi L. Agenesis and microdontia of permanent teeth as late adverse effects after stem cell transplantation in young children. Cancer. 2005;103(1):181-90. doi: 10.1002/cncr.20762

9- Visinoni AF, Lisboa-Costa T, Pagnan NA, Chautard-Freire-Maia EA. Ectodermal dysplasias: clinical and molecular review. Am J Med Genet A. 2009;149A(9):1980-2002. doi: 10.1002/ajmg.a.32864 10- Cobourne MT. Familial human hypodontia: is it all in the genes? $\mathrm{Br}$ Dent J. 2007;203(4):203-8. doi: 10.1038/bdj.2007.732

11- Yin W, Bian Z. Hypodontia, a prospective predictive marker for tumor? Oral Dis. 2016;22(4):265-73. doi: 10.1111/odi.12400

12- Arte S, Parmanen S, Pirinen S, Alaluusua S, Nieminen P. Candidate gene analysis of tooth agenesis identifies novel mutations in six genes and suggests significant role for WNT and EDA signaling and allele combinations. PLoS One. 2013;8(8):e73705. doi: 10.1371/journal. pone. 0073705

13- Kimura M, Machida J, Yamaguchi S, Shibata A, Tatematsu T, Miyachi $H$, et al. Novel nonsense mutation in MSX1 in familial nonsyndromic oligodontia: subcellular localization and role of homeodomain/MH4. Eur J Oral Sci. 2014;122(1):15-20. doi: 10.1111/eos.12105

14- Liang J, Song G, Li Q, Bian Z. Novel missense mutations in PAX9 causing oligodontia. Arch Oral Biol. 2012;57(6):784-9. doi: 10.1016/j. archoralbio.2011.12.005

15- Clauss F, Waltmann E, Barriere P, Hadj-Rabia S, Maniere MC, Schmittbuhl M. Dento-maxillo-facial phenotype and implants-based oral rehabilitation in Ectodermal Dysplasia with WNT10A gene mutation: report of a case and literature review. J Craniomaxillofac Surg. 2014;42(6):e346-51. doi: 10.1016/j.jcms.2014.01.037 16- Hlouskova A, Bielik P, Bonczek O, Balcar VJ, Šerý O. Mutations in AXIN2 gene as a risk factor for tooth agenesis and cancer: a review. Neuro Endocrinol Lett. 2017;38(3):131-7

17- Hsu DS, Acharya CR, Balakumaran BS, Riedel RF, Kim MK, Stevenson $M$, et al. Characterizing the developmental pathways TTF-1, NKX2-8, and PAX9 in lung cancer. Proc Natl Acad Sci U S A. 2009;106(13):5312-7. doi: 10.1073/pnas.0900827106 18- Menezes ME, Mitra A, Shevde LA, Samant RS. DNAJB6 governs a novel regulatory loop determining $\mathrm{Wnt} /$ beta-catenin signalling activity. Biochem J. 2012;444(3):573-80. doi: 10.1042/BJ20120205 
19- Lammi L, Arte S, Somer M, Jarvinen H, Lahermo P, Thesleff I, et al. Mutations in AXIN2 cause familial tooth agenesis and predispose to colorectal cancer. Am J Hum Genet. 2004;74(5):1043-50. doi: $10.1086 / 386293$

20- Rauch TA, Wang Z, Wu X, Kernstine KH, Riggs AD, Pfeifer GP. DNA methylation biomarkers for lung cancer. Tumour Biol. 2012;33(2):28796. doi: 10.1007/s13277-011-0282-2

21- Chalothorn LA, Beeman CS, Ebersole JL, Kluemper GT, Hicks EP, Kryscio RJ, et al. Hypodontia as a risk marker for epithelial ovarian cancer: a case-controlled study. J Am Dent Assoc. 2008;139(2):163-9. doi: 10.14219/jada.archive.2008.0132

22- Fekonja A, Čretnik A, Takač I. Hypodontia prevalence and pattern in women with epithelial ovarian cancer. Angle Orthod. 2014;84(5):810-4. doi: 10.2319/112813-876.1

23- Bonds J, Pollan-White S, Xiang L, Mues G, D'Souza R. Is there a link between ovarian cancer and tooth agenesis? Eur J Med Genet. 2014;57(5):235-9. doi: 10.1016/j.ejmg.2014.02.013

24- Paranjyothi MV, Kumaraswamy KL, Begum LF, Manjunath K, Basheer S. Tooth agenesis: a susceptible indicator for colorectal cancer? J Cancer Res Ther. 2018;14(3):527-31. doi: 10.4103/0973-1482.168997 25- Moher D, Liberati A, Tetzlaff J, Altman DG, PRISMA Group. Preferred reporting items for systematic reviews and meta-analyses: the PRISMA statement. PLoS Med. 2009;6(7):e1000097. doi: 10.1371/journal. pmed. 1000097

26- Wells G, Shea B, O'Connell J, Peterson J, Welch V, Losos M, et al. The Newcastle-Ottawa Scale (NOS) for assessing the quality of nonrandomised studies in meta-analyses [Internet]. Ottawa Health Research Institute; 2013 [cited 2020 Feb 20]. Avaiable from: http:// www.ohri.ca/programs/clinical_epidemiology/oxford.asp

27- Balshem $H$, Helfand M, Schünemann HJ, Oxman AD, Kunz R, Brozek J, et al. GRADE guidelines: 3. Rating the quality of evidence. J Clin Epidemiol. 2011;64(4):401-6. doi: 10.1016/j.jclinepi.2010.07.015 28- Küchler EC, Lips A, Tannure PN, Ho B, Costa MC, Granjeiro JM, et al. Tooth agenesis association with self-reported family history of cancer. J Dent Res. 2013;92(2):149-55. doi: 10.1177/0022034512468750 29- Lindor NM, Win AK, Gallinger S, Daftary D, Thibodeau SN, Silva R, et al. Colorectal cancer and self-reported tooth agenesis. Hered Cancer Clin Pract. 2014;12(1):7. doi: 10.1186/1897-4287-12-7

30- Williams MA, Biguetti C, Romero-Bustillos M, Maheshwari K, Dinckan $\mathrm{N}$, Cavalla F, et al. Colorectal cancer-associated genes are associated with tooth agenesis and may have a role in tooth development. Sci Rep. 2018;8(1):2979. doi: 10.1038/s41598-018-21368-z

31- Klein OD, Oberoi S, Huysseune A, Hovorakova M, Peterka M, Peterkova R. Developmental disorders of the dentition: an update. Am J Med Genet C Semin Med Genet. 2013;163C(4):318-32. doi: 10.1002/ajmg.c.31382

32- Lejeune S, Guillemot F, Triboulet JP, Cattan S, Mouton C, PAFNORD Group, et al. Low frequency of AXIN2 mutations and high frequency of MUTYH mutations in patients with multiple polyposis. Hum Mutat. 2006;27(10):1064. doi: 10.1002/humu.9460

33- Marvin ML, Mazzoni SM, Herron CM, Edwards S, Gruber SB, Petty EM. AXIN2-associated autosomal dominant ectodermal dysplasia and neoplastic syndrome. Am J Med Genet A. 2011;155A(4):898-902. doi: 10.1002/ajmg.a.33927

34- Stearns FW. One hundred years of pleiotropy: a retrospective. Genetics. 2010;186(3):767-73. doi: 10.1534/genetics.110.122549

35- Solovieff N, Cotsapas C, Lee PH, Purcell SM, Smoller JW. Pleiotropy in complex traits: challenges and strategies. Nat Rev Genet. 2013;14(7):483-95. doi: $10.1038 / n r g 3461$
36- Vieira AR, Khaliq $S$, Lace B. Risk of cancer in relatives of children born with isolated cleft lip and palate. Am J Med Genet A. 2012;158A(6):1503-4. doi: 10.1002/ajmg.a.35359

37- Fournier BP, Bruneau MH, Toupenay S, Kerner S, Berdal A, CormierDaire $V$, et al. Patterns of dental agenesis highlight the nature of the causative mutated genes. J Dent Res. 2018;97(12):1306-16. doi: $10.1177 / 0022034518777460$

38- Wang J, Sun K, Shen Y, Xu Y, Xie J, Huang R, et al. DNA methylation is critical for tooth agenesis: implications for sporadic non-syndromic anodontia and hypodontia. Sci Rep. 2016;6:19162. doi: 10.1038/ srep19162

39- Ye X, Attaie AB. Genetic basis of nonsyndromic and syndromic tooth agenesis. J Pediatr Genet. 2016;5(4):198-208. doi: 10.1055/s0036-1592421

40- Jonsson L, Magnusson TE, Thordarson A, Jonsson T, Geller F, Feenstra $B$, et al. Rare and common variants conferring risk of tooth agenesis. J Dent Res. 2018;97(5):515-22. doi: 10.1177/0022034517750109 41- Otero L, Lacunza E, Vasquez V, Arbelaez V, Cardier F, González F. Variations in AXIN2 predict risk and prognosis of colorectal cancer. BDJ Open. 2019;5:13. doi: 10.1038/s41405-019-0022-z

42- Letra A, Menezes R, Granjeiro JM, Vieira AR. AXIN2 and CDH1 polymorphisms, tooth agenesis, and oral clefts. Birth Defects Res $A$ Clin Mol Teratol. 2009;85(2):169-73. doi: 10.1002/bdra.20489

43- Xu B, Yuan W, Shi L, Zuo L, Wu XY, Zhang W, et al. New insights into the association between AXIN2 $148 \mathrm{C} / \mathrm{T}, 1365 \mathrm{C} / \mathrm{T}$, and rs4791171 A/G variants and cancer risk. Cancer Cell Int. 2019;19:119. doi: 10.1186/ s12935-019-0840-z

44- Gawron-Jakubek W, Spaczynska J, Pitynski K, Loster BW. Coexistence of tooth agenesis and ovarian cancer: a systematic literature review. Ginekol Pol. 2019;90(12):707-10. doi: 10.5603/ GP.2019.0121

45- Bolton KL, Ganda C, Berchuck A, Pharaoh PD, Gayther SA. Role of common genetic variants in ovarian cancer susceptibility and outcome: progress to date from the ovarian cancer association consortium (OCAC). J Intern Med. 2012;271(4):366-78. doi: 10.1111/j.13652796.2011.02509.x

46- Lustig B, Behrens J. The Wnt signaling pathway and its role in tumor development. J Cancer Res Clin Oncol. 2003;129(4):199-221. doi: 10.1007/s00432-003-0431-0

47- Berns EMJJ, Bowtell DD. The changing view of high-grade serous ovarian cancer. Cancer Res. 2012;72(11):2701-4. doi: 10.1158/00085472. CAN-11-3911

48- Ledermann JA, Raja FA, Fotopoulou C, Gonzalez-Martin A, Colombo $N$, Sessa $C$, et al. Newly diagnosed and relapsed epithelial ovarian carcinoma: ESMO Clinical Practice Guidelines for diagnosis, treatment and follow-up. Ann Oncol. 2013;24(Suppl 6):vi24-vi32. doi: 10.1093/ annonc/mdt333

49- Jayson GC, Kohn EC, Kitchener HC, Ledermann JA. Ovarian cancer. Lancet. 2014;384(9951):1376-88. doi: 10.1016/S01406736(13)62146-7

50- Fekonja A, Cretnik A, Zerdoner D, Takac I. Hypodontia phenotype in patients with epithelial ovarian cancer. Radiol Oncol. 2015;49(1):6570. doi: 10.2478/raon-2014-0034

51- Lheureux S, Gourley C, Vergote I, Oza AM. Epithelial ovarian cancer. Lancet. 2019;393(10177):1240-53. doi: 10.1016/S01406736(18)32552-2

52- Ritwik P, Patterson KK. Diagnosis of tooth agenesis in childhood and risk for neoplasms in adulthood. Ochsner J. 2018;18(4):345-50. doi: $10.31486 /$ toj. 18.0060 